\title{
MiR-132 Regulates Rem Expression in Cardiomyocytes During Long-Term $\beta$-Adrenoceptor Agonism
}

\author{
Elba D. Carrillo Raúl Sampieri Ascención Hernández María C. García \\ Jorge A. Sánchez
}

Departamento de Farmacología. Centro de Investigación y de Estudios Avanzados del I.P.N. México, D.F. 07360. México

\section{Key Words}

L-type calcium channel $\cdot$ miR-132 $\cdot$ miR-214 $\cdot$ Rem $\cdot$ microRNAs $\cdot$ Isoproterenol $\cdot \alpha_{1 c}$ Subunit Cav1.2 channel $\bullet$ L-type $\mathrm{Ca}^{2+}$ currents $\bullet \mathrm{Ca}^{2+}$ transients

\begin{abstract}
Aims: To characterize the effects of long-term $\beta$-adrenergic receptor stimulation on Rem protein and mRNA expression in rat heart and possible involvement of miR-132. Methods: Adult rats were treated with isoproterenol (ISO, $150 \mu \mathrm{g} . \mathrm{kg}^{\mathrm{h}}{ }^{-1}$ ) for $2 \mathrm{~d}$ and Rem, miR-132, and $\alpha_{1 c}$ (the principal subunit of Cav1.2 channels) were measured at protein and mRNA levels with western blot and quantitative reverse transcriptase polymerase chain reaction (qRT$\mathrm{PCR}$ ) experiments, respectively. $\mathrm{Ca}^{2+}$ currents and intracellular $\mathrm{Ca}^{2+}$ signals were evaluated in isolated cardiomyocytes. Results: Systemic administration of ISO led to decreases in Rem protein and mRNA levels (down to 49\%). Furthermore, levels of the microRNAs (miRs) miR-132 and miR-214 were upregulated 5- and 9-fold, respectively. Transfection of miR-132, but not miR-214, into HEK293 cells reduced the expression of a luciferase reporter gene controlled by a conserved 3'-untranslated region (UTR) of Rem by half. Chronic ISO administration also led to a $25 \%$ decrease in the amplitude of peak L-type $\mathrm{Ca}^{2+}$ currents, a $40 \%$ decrease in $\alpha_{1 \mathrm{c}}$ subunit protein abundance at the membrane level, and a $60 \%$ decrease in expression of $\alpha_{1 c}$ channel subunit mRNA. Conclusions: These results suggest that Rem expression is down-regulated posttranscriptionally by miR-132 in response to long-term activation of $\beta$-adrenergic signaling, but this down-regulation does not produce a larger $\mathrm{Ca}^{2+}$ influx through Cav1.2 channels.
\end{abstract}




\section{Cellular Physiology Cell Physiol Biochem 2015;36:141-154 \\ \begin{tabular}{l|l} 
and Biochemistry Published online: April 30, 2015 & $\begin{array}{l}\text { C) 2015 S. Karger AG, Basel } \\
\text { www.karger.com/cpb }\end{array}$ \\
\hline
\end{tabular} \\ Carrillo et al.: Isoproterenol and Rem Expression}

\section{Introduction}

Studies in many systems have shown that microRNAs (miRs), small non-coding RNAs, repress gene expression posttranscriptionally by binding to discrete miR regulatory elements (MREs) typically located in the 3'-untranslated region (UTR) of target mRNAs [1, 2]. Regulation of target mRNAs is dependent on the degree of complementarity between a miR and the MRE sequence being bound [1] as well as the number of MREs present [3]. miRs can repress expression of target genes by promoting mRNA degradation, inhibiting translation, or both $[1,4-6]$, with the relative contribution of each mechanism varying across cell types. miRs have been implicated in organogenesis and differentiation of cells [7], and in particular miR-132 has been implicated in differentiation of periodontal ligament cells, but no direct targets of this microRNA were defined [8].

In recent years, miRNA dysregulation has been implicated in a number of human diseases, including cancer, Alzheimer disease, psychiatric disorders, and cardiac hypertrophy [7]. Cardiac hypertrophy has been shown to depend on the presence of miR-132, which is upregulated in cardiomyocytes following exposure to hypertrophizing stimuli. The only target of miR-132 identified in heart muscle thus far is Forkhead box 03, a powerful antihypertrophic transcription factor that is suppressed by miR-132 [9].

Cav1.2 channels (L-type $\mathrm{Ca}^{2+}$ channels) are critically involved in excitation-contraction coupling and $\mathrm{Ca}^{2+}$ homeostasis in the heart and other tissues [10]. In cardiomyocytes, stimulation of $\beta$-adrenergic receptors promotes cAMP-mediated phosphorylation of Cav1.2 channels, resulting in a transient increase in $\mathrm{Ca}^{2+}$ influx and myocyte contraction (see reviews by Shabb, [11] and Van der Heyden et al., [12]). Although beneficial in the short term, if sustained, these changes lead to cardiac hypertrophy (see review by Nichtova [13]). Hence, chronic $\beta$-adrenergic signaling has been implicated in the development of cardiac hypertrophy, possibly through a pathway involving Cav1.2 channels, though the exact mechanism by which this may occur is unclear. In rats, development of cardiac hypertrophy becomes apparent within days of $\beta$-adrenergic receptor stimulation [14-16]. Indeed $\beta$-adrenergic receptor agonism with isoproterenol (ISO) has been shown to alter the expression of a variety of genes associated with the development of cardiomyocyte hypertrophy [17]. In human hypertensive patients, Greenwood et al. [18] found that left ventricular hypertrophy was associated with a high sympathetic discharge. Determining the signaling mechanisms that underlie pathological processes underlying cardiac hypertrophy may provide information necessary for preventing and treating the condition.

There are numerous agents that influence $\mathrm{Ca}^{2+}$ influx. Among them, small GTPases are especially potent regulators of Cav1.2 channels (reviewed by Flynn and Zamponi [19]). Small GTPases are members of the RGK protein subfamily, which is a division of the Ras superfamily, There are four distinct members in this subfamily: Rad, Gem/Kir, Rem (also known as Rem1) and Rem2, which are differentially expressed in several tissues. Rad is expressed most prominently in skeletal muscle, expressed at moderate levels in lung and heart, and expressed at extremely low levels in kidney and brain [20]. Conversely, Gem is expressed at high levels in kidney, expressed to a lesser extent in lung and spleen, and has very low expression levels in heart and skeletal muscle tissues [21]. Rem2 is abundant in the brain, significantly expressed in the kidney, and barely detectable in heart and skeletal muscle [22]. Meanwhile, Rem is distinguished from other RGK proteins by its strong expression in heart, with relatively low abundance in skeletal muscle, kidney, and lung, and very low expression in brain [23]. Rem expression in heart cells is regulated by adrenergic receptor activation. Chronic $\beta$-adrenoceptor stimulation has been reported to alter Rem mRNA expression in mice [24] and Rem becomes phosphorylated in human cells after sustained application of $\alpha$-adrenoceptor agonists [25]. Thus, given that elevated intracellular $\mathrm{Ca}^{2+}$ has been linked to cardiac hypertrophy [26], we would expect dysregulation of Rem expression to alter Cav1.2 channel function and $\mathrm{Ca}^{2+}$ homeostasis.

Thus, the primary aims of the present study were firstly to characterize the effects of long-term $\beta$-adrenergic receptor stimulation on Rem expression at the protein and 


\section{Cellular Physiology Cell Physiol Biochem 2015;36:141-154 \begin{tabular}{l|l|l}
\hline DOI: 10.1159/000374059 & C 2015 S. Karger AG, Basel
\end{tabular} \begin{tabular}{l|l} 
and Biochemistry Published online: April 30, 2015 & www.karger.com/cpb
\end{tabular} \\ Carrillo et al.: Isoproterenol and Rem Expression}

mRNA levels in the adult rat heart. Secondly, we examined the role of miRs in such effects. Specifically, the focus in our miR experiments was based on prior microarray results obtained by Carrillo and colleagues in experimental conditions similar to ours and related work in our laboratory. Carrillo et al. [16] found that 12 miRs were upregulated by ISO, and among those, we identified two, namely miR-132 and miR-214, as candidate regulators of Rem based on visual examination of the base-pairing of reported miRs with the 3'-UTR of rat Rem using RNAhybrid software [27]. Finally, the effects of ISO on $\mathrm{Ca}^{2+}$ current amplitude and on expression of the $\alpha_{1 c}$ channel subunit of Cav1.2 channels were assessed. The present study focused on Rem because this RGK is preferentially expressed in heart and Rem inhibition of L-type channels has been studied in detail (reviewed by Flynn and Zamponi, [19]).

\section{Materials and Methods}

\section{Animals}

The experiments were performed on adult male Wistar rats (200-250 g) according to protocols approved by the Division Laboratory Animal Unit (CICUAL) at Cinvestav, Mexico, approval ID 1101010108 (protocol No. 0258-05), in compliance with state law, federal statute and CONACyT policy.

\section{ISO treatment}

Rats were anesthetized by intraperitoneal injection of a solution consisting of $10 \%$ xylazine chlorohydrate (4 mg/kg, Pisa Agropecuaria, Atitalaquia, HI, Mexico) and Ketalin (80 mg/kg, Pisa Agropecuaria, Atitalaquia, HI, Mexico). A small lateral incision was made on the back of each rat's neck, and an osmotic minipump (Model 2ML2, Alzet, Cupertino, CA, USA) was implanted. $d l$-isoproterenol- $\mathrm{HCl}$ (Sigma-Aldrich) was administered via minipump for $2 \mathrm{~d}$ at a rate of $150 \mu \mathrm{g} / \mathrm{kg} / \mathrm{h}$ in normal saline solution as vehicle. This dose of ISO is within the range used in previous rat studies [16, 17]. A similar solution lacking ISO was administered in the same manner to control animals. Following the minipump infusion period, rats were anesthetized again, as described above, and their hearts were excised and processed as described below. The effects of 6-h and 12-h ISO were investigated following a subcutaneous injection at a concentration of $5 \mathrm{mg} / \mathrm{kg}$.

\section{Isolation of ventricular myocytes}

Ventricular myocytes were isolated as described previously [28]. Briefly, hearts were rapidly excised and perfused in a Langendorff apparatus with an aortic cannula delivering $37 \pm 0.5^{\circ} \mathrm{C}$ buffer at $66 \mathrm{mmHg}$ and were perfused for 5 min with $\mathrm{Ca}^{2+}$-free Tyrode solution (containing in mM: $136 \mathrm{NaCl}, 5.4 \mathrm{KCl}, 1 \mathrm{MgCl}_{2}, 10$ HEPES, and 11 glucose plus heparin [10 U/mL], Sigma-Aldrich), followed by 30 min with Tyrode solution containing 20-40 $\mu \mathrm{M} \mathrm{CaCl}_{2}, 0.1 \%$ bovine serum albumin (BSA), collagenase (type II, $70 \mathrm{U} / \mathrm{ml}$; Worthington, Lakewood, NJ, USA), and protease type XIV (0.5 mg/100 ml; Sigma-Aldrich). Dissected ventricles were minced and shaken at $45 \mathrm{rpm}$ for $7 \mathrm{~min}$ in the same solution 2-3 times. Ventricular cells were filtered through a cell strainer $(100 \mu \mathrm{m}$ nylon, BD Falcon $)$ and centrifuged at $700 \times g$ for $2 \mathrm{~min}$. The pellet was re-suspended in Tyrode solution (containing in mM: $136 \mathrm{NaCl}, 5.4 \mathrm{KCl}, 2 \mathrm{MgCl}_{2}, 10 \mathrm{HEPES}_{2} 2 \mathrm{CaCl}_{2}$ and 11 glucose, plus 1\% BSA). Myocytes were used immediately.

\section{Western blot analysis}

Immunoblots were performed as described previously [29]. In brief, frozen $\left(-80^{\circ} \mathrm{C}\right)$ pulverized rat ventricles were subjected to Dounce homogenization in 10 volumes of homogenization medium (250 mM sucrose, $50 \mathrm{mM}$ MOPS, $2 \mathrm{mM}$ EGTA, pH 7.4) with the following protease inhibitors added: 1 mM benzamidine, $1 \mathrm{mM}$ leupeptin, $0.1 \mathrm{mM}$ aprotinin, $1 \mathrm{mM}$ pepstatin A, $0.2 \mathrm{mM} \mathrm{PMSF}$, and $0.4 \mathrm{mM}$ pefabloc. The homogenates were centrifuged at $1000 \times g$ for $10 \mathrm{~min}$. The supernatant was recovered and centrifuged at $5000 \times g$ for $10 \mathrm{~min}$. The pellet was discarded and the supernatant was centrifuged at 100,000 $\times g$ for $1 \mathrm{~h}$. The final pellet, an enriched cell membrane fraction, was re-suspended in $100 \mu$ l homogenization medium. The final supernatant was a cytosolic fraction.

For analysis of the $\alpha_{1 \mathrm{c}}$ channel subunit and cadherin, a sample of the pellet ( $80 \mu \mathrm{g}$ ) was loaded on an $8 \%$ polyacrylamide gel. Meanwhile, for analysis of Rem and GAPDH, a sample of the supernatant (40 


\section{Cellular Physiology Cell Physiol Biochem 2015;36:141-154 \begin{tabular}{l|l|l}
\hline DOI: 10.1159/000374059 & C 2015 S. Karger AG, Basel
\end{tabular} \begin{tabular}{l|l} 
and Biochemistry Published online: April 30, 2015 & www.karger.com/cpb
\end{tabular} \\ Carrillo et al.: Isoproterenol and Rem Expression}

$\mu \mathrm{g}$ ) was loaded on a $10 \%$ polyacrylamide gel and subjected to sodium dodecyl sulfate-polyacrylamide gel electrophoresis. It is believed that Rem signals from ventricle lysates originate selectively from cardiomyocytes because Rem is not expressed in fibroblasts [30]. Protein content was measured by the Bradford assay method [31] to confirm equal loading of gels.

Proteins were transferred to nitrocellulose membranes and Ponceau stained [32]. The transferred protein bands were probed in PBS solution with anti-Rem monoclonal antibody (1:1000; Abcam, Cambridge, England) or anti-GAPDH monoclonal antibody (1:10000; Sigma-Aldrich, St. Louis, MO, USA) for normalization. Anti- $\alpha_{1 c}$ channel subunit polyclonal (1:100; Alomone Labs) and anti-pan cadherin monoclonal (1:1000; Abcam) antibodies were also used. After rinsing away excess primary antibodies with PBS plus tween $(0.1 \%)$, the membranes were incubated with anti-rabbit $(1: 70,000)$ or anti-mouse $(1: 70,000)$ horseradish peroxidase-conjugated secondary antibody (Invitrogen, Carlsbad, CA, USA). Chemiluminescence was detected with Immobilon Western reagent (Millipore) and band densities were measured as previously described [28].

\section{Measurement of $\mathrm{Ca}^{2+}$ transients}

Intracellular $\mathrm{Ca}^{2+}$ levels were monitored with Fluo-3 AM (Molecular Probes, Eugene, OR, USA) as described previously [28]. This dye undergoes a marked shift in fluorescence upon $\mathrm{Ca}^{2+}$ binding. Adult cardiomyocytes were loaded with approximately $5 \mu \mathrm{M}$ Fluo-3 AM in standard Tyrode solution for 40 min at room temperature. After loading, cells were incubated in dye-free solution for over 30 min to allow conversion of the dye to its $\mathrm{Ca}^{2+}$-sensitive, free-acid form. Dye-loaded cells were placed on a laminincoated coverslip at the bottom of a chamber on the stage of an Optiphot microscope (Nikon, Tokyo, Japan). Stained myocytes were illuminated episcopically with monochromatic light ( $485 \mathrm{~nm}$ ). Emitted fluorescence was filtered with a high-pass barrier filter (cut-off wavelength $535 \mathrm{~nm}$ ) and detected with a low-noise photodiode in a photovoltaic configuration. Analog signals were digitized and sampled every $60 \mu$ for 40 s. $\mathrm{Ca}^{2+}$ signals were calculated as $\Delta \mathrm{F} / \mathrm{F}$, where $\mathrm{F}$ was the basal fluorescence of the myocyte, determined as the mean recorded value over the 300 -ms interval prior to electrical stimulation and $\Delta \mathrm{F}$ were values poststimulation. To induce $\mathrm{Ca}^{2+}$ transients during action potentials, myocytes were stimulated electrically with two extracellular platinum electrodes at a frequency of $0.3 \mathrm{~Hz}$. To estimate the duration of the transients, we measured the half-width, which is the full duration of the signals at half-maximal amplitude. Because this study was designed to detect temporal and relative patterns of $\mathrm{Ca}^{2+}$ transients, absolute value measurements of intracellular $\mathrm{Ca}^{2+}$ concentration were not made.

\section{RNA isolation and reverse transcription}

Cellular RNA was isolated with the RNeasy Mini kit (Qiagen). Reverse transcription was performed with 500 ng of DNAse-treated RNA in 20- $\mu$ L reactions. Synthesis of cDNA was carried out with Superscript III reverse transcriptase (Invitrogen) and random hexamers (250 ng) following the manufacturer's instructions.

Quantitative reverse transcriptase polymerase chain reaction ( $q R T-P C R$ )

The relative expression levels of Rem and $\alpha_{1 \mathrm{c}}$ mRNA were quantified using TaqMan assays (Applied Biosystems, Foster City, CA, USA). 18S ribosomal RNA (rRNA), which performs consistently for most applications [33] and is unaffected by ISO administration, was used as an internal control. Quantification was performed by the $2^{-\Delta \Delta C t}$ method [34]. This procedure is valid if the amplification efficiencies of the target and reference genes are approximately equal, as was the case in our experiments.

\section{Analysis of miR expression}

miR-RNA was isolated with a miRNeasy Mini kit (Qiagen). The relative expression levels of rnomiR-132 and rno-miR-214 were quantified using TaqMan miR assays (Applied Biosystems, Foster City, CA, USA). miR expression was assessed relative to the small nucleolar RNA U87, as recommended by the manufacturer. Changes in expression levels were calculated using the $2^{-\Delta \Delta C T}$ method [34].

Cloning of Rem 3'-UTR

The 3'-UTR of Rem (Rattus norvegicus RAS (RAD and GEM)-like GTP-binding 1, Acc. No. [NM_001025753.1]) was amplified from the cDNA of rat ventricles using primers: forward 3'UTR: 5'-TTA 


\section{Cellular Physiology Cell Physiol Biochem 2015;36:141-154 \begin{tabular}{l|l} 
DOI: 10.1159/000374059 & (c) 2015 S. Karger AG, Basel
\end{tabular} and Biochemistry $\frac{\text { Published online: April 30, } 2015}{\text { Carrillo et al.: Isoproterenol and Rem Expression }}$

AGC TAG CGG CCA GCG TCT CTC TGG GGC-3’ and reverse 3’UTR:5'-CCC CCC CCC CCG CTA GCT TTT TTT TTT TTT TTT TTT TTT TTT ATA ATT AAT TCA TTG ACT TTA TTG ATT GTC CAA GAC-3’. The amplified region was ligated at the Xba I site downstream of the luciferase-encoding region of the pGL3 vector (Promega GmbH, Mannheim, Germany). Cloning fidelity was verified by DNA sequencing.

\section{Luciferase reporter assay}

For luciferase reporter assays, HEK293 cells were seeded in 24-well plates $(\sim 40,000 /$ well $)$ and cultured in DMEM medium supplemented with $10 \%$ fetal bovine serum at $37{ }^{\circ} \mathrm{C}$ and $5 \% \mathrm{CO}_{2}$. Cells were transfected with 100 ng of pGL3 Rem 3'-UTR plasmid with Lipofectamine 2000 (Invitrogen) according to the manufacturer's instructions. Co-transfections were performed with $60 \mathrm{nM}$ of pre-miR-132 (PM10166, Ambion), pre-miR-214 (PM11376, Ambion), or pre-miRNA precursor control 1 (AM17110, Ambion) as a negative control. Luciferase activity assays were performed $48 \mathrm{~h}$ after transfection with the SteadyGlo Luciferase Assay System (Promega, Madison, WI, USA) and a Modulus Single Tube Reader (Turner Biosystems, Sunnyvale, CA, USA). Luciferase activity was normalized to sample protein concentration [31]. All reporter assays were performed in triplicate. The luciferase reporter assay is a typical procedure used to verify predicted miR/mRNA pairings and measure construct expression [35].

\section{Electrophysiology}

The whole-cell patch-clamp technique was used to record L-type $\mathrm{Ca}^{2+}$ currents in dissociated ventricular myocytes as described elsewhere [28]. Currents were recorded with an Axopatch 200-A amplifier (Axon Instruments) with the holding potential set to $-80 \mathrm{mV}$. The pulse protocol involved a $65-\mathrm{ms}$ pulse to $-40 \mathrm{mV}$ to inactivate $\mathrm{Na}^{+}$currents followed by 20 consecutive 65 -ms pulses to preselected potentials in $+5 \mathrm{mV}$ steps to activate L-type $\mathrm{Ca}^{2+}$ currents. To measure membrane capacitance and to subtract linear currents, the membrane was clamped to the holding potential and a $+5 \mathrm{mV}$ pulse lasting $62 \mathrm{~ms}$ was applied. Current records were digitized with a Digidata interface (Axon Instruments, Foster City, CA, USA) at a 16-bit resolution. The data were analyzed in pCLAMP 8.0 (Axon Instruments) and in-house software.

Peak $\mathrm{Ca}^{2+}$ channel current values were fitted to equation (1), which describes the current-voltage relationship of L-type currents.

$\operatorname{Im}=\operatorname{Gmax} \bullet(V m-$ Vrev $)\{1+\exp [(V-V m) / k]\}$

Gmax is the maximum conductance, Vrev is the reversal potential, $\mathrm{Vm}$ is the membrane potential during depolarizing pulses, $V$ is the potential at which $\mathrm{G}=0.5 \mathrm{Gmax}$, and $\mathrm{k}$ is a measure of the steepness of the curve. Numerical formulae were fitted to our experimental data using a non-linear, least-squares algorithm. The pipette solution contained (in mM): 100 cesium aspartate, $20 \mathrm{CsCl}, 20 \mathrm{TEACl}, 2 \mathrm{Mg}$-ATP, 1.8, $\mathrm{MgCl}_{2}, 0.05$ EGTA and 5 HEPES, pH 7.2. The standard bath solution was Tyrode solution containing $1 \mathrm{mM}$ $\mathrm{Ca}^{2+}$. Experiments were performed at room temperature $\left(23^{\circ} \mathrm{C}\right)$.

\section{Data analysis}

Results data are expressed as means \pm standard errors (SEs). Statistical analyses were performed with GraphPad Prism 4.0 (GraphPad Software) and Sigma Stat 2.0; unpaired t-tests, paired t-tests, and oneway analyses of variance (ANOVAs) were used as appropriate. A $P<0.05$ was considered to be statistically significant.

\section{Results}

Hypertrophic effect of ISO

ISO treatment for $2 \mathrm{~d}$ had a hypertrophic effect on hearts under our experimental conditions. The mean ventricular weight to body weight ratio was $38 \%$ greater in ISOtreated rats $(3.4 \pm 0.2 \mathrm{mg} / \mathrm{g}, \mathrm{n}=14)$ than in controls $4.7 \pm 0.3(\mathrm{n}=13)$.

\section{Long-term ISO administration decreases Rem expression}

Western blot analysis demonstrated that Rem protein expression was significantly decreased in ventricle lysates isolated from $2 \mathrm{~d}$ ISO-treated rats compared with that in lysates from vehicle-infused controls, while GAPDH levels were unaffected by the drug treatment 
Fig. 1. Effects of chronic ISO on Rem protein and mRNA levels. $A-B$ : Immunoblots from control (left) and 2-d ISO-treated (right) ventricle cytosolic samples representing Rem (A) and GAPDH (B) protein levels. C: Quantitative analysis of Rem protein band density from control (open bar) and ISO-treated (filled bar) rats. Values were normalized to GAPDH band densities $\left(n=6,{ }^{*} p\right.$ <.01). D: Quantitative analysis of Rem mRNA expression in ventricle lysates from control (open bar) and ISO-treated (filled bar) rats $\left(n=4,{ }^{*} p<.01\right)$. All values are group means \pm SEs.

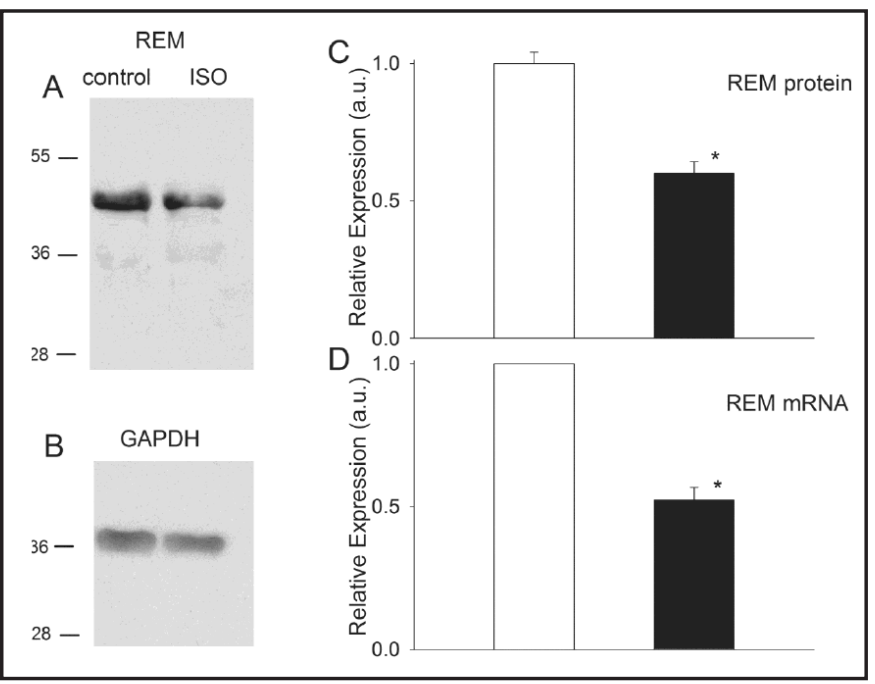

Fig. 2. Posttranscriptional regulation of Rem expression by miRs. A: miR-132 and miR-214 seed sites within the Rem 3'-UTR. Note that nucleotides 2 through 8 exhibit perfect complementarity in both cases. Bases paired by Watson-Crick bonds are depicted with a vertical black line, and G:U pairs are depicted by a double-dotted vertical line. $B$ : Quantitative analysis of miR levels determined by qRT-PCR and $2^{-\triangle A C T}$ in ventricle samples from ISO-treated $v s$. control animals. U87 was used for normalization ( $n=6$ per group, ${ }^{*} p<.01$ ). C: Quantitative analysis of luciferase reporter gene activity in HEK-293 cells expressing pGL3 vectors with Rem 3'-UTR in combination with a negative control, or with indicated miRs ( $n$ $=10-12$ per group, ${ }^{*} p<.01$ ). All values are group means \pm SEs.

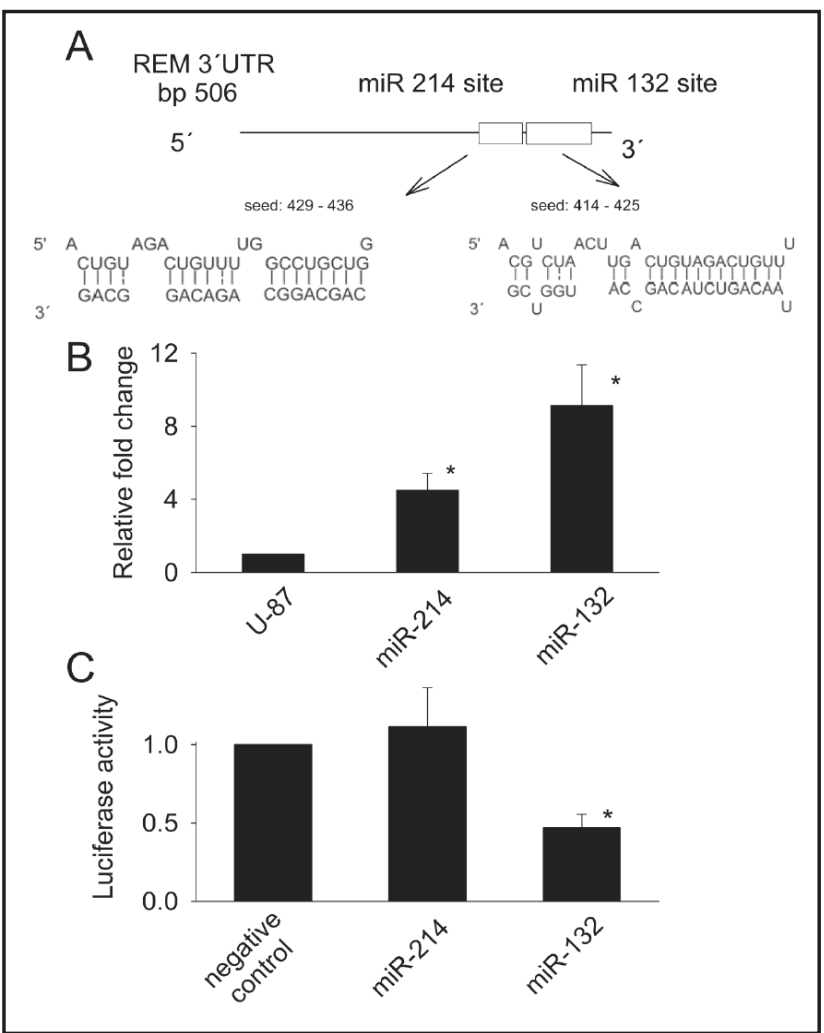

(Fig. 1A-C). Long-term ISO administration decreased Rem protein levels by approximately $40 \%$. Furthermore, the qRT-PCR experiments indicated that the ISO treatment decreased Rem mRNA levels significantly, with the ISO group having levels that were $\sim 50 \%$ of control group levels (Fig. 1D).

\section{Posttranscriptional miR regulation of Rem $m R N A$}

qRT-PCR experiments showed that both miR-132 and miR-214 were upregulated by ISO within $48 \mathrm{~h}$, with miR-132 having a noteworthy more than 6 -fold increase (Fig. 2B). The binding sites for these two miRs within the 3'-UTR region of the rat Rem gene are shown in Figure 2A. Luciferase reporter gene assays in cells expressing the 3'UTR region of Rem showed that miR-132 repressed luciferase activity significantly, by $60 \%$, but miR-214 did not have a significant effect on luciferase activity (Fig. 2C). 

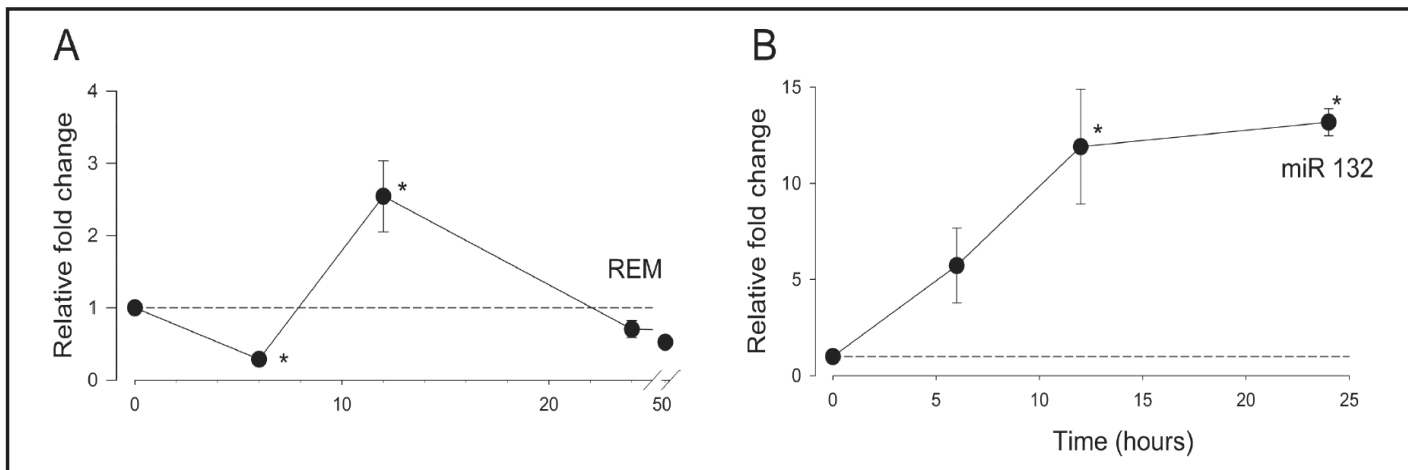

Fig. 3. ISO effects on Rem mRNA and miR-132. A: Relationship between ISO administration time and the relative expression of Rem mRNA. ( $n=4$ per group). $B$ : The effect of chronic ISO on the relative expression of miR-132 ( $n=3$ per group). Level of expression at $t=0$ is shown with a dotted line in both graphs. All values are group means \pm SEs $\left({ }^{*} p<.05\right)$.

Fig. 4. Effects of chronic ISO on Rem protein levels. A: Immunoblots from control (left) and 12-h or 24-h ISO-treated ventricle cytosolic samples (right). Blots represent Rem and GAPDH protein levels. $B$ : Quantitative analysis of Rem protein band density as a function of treatment duration. Values were normalized to GAPDH band densities $\left(n=3,{ }^{*} p<.05\right)$. Level of expression at $\mathrm{t}=0$ is shown with a dotted line. All values are group means \pm SEs.

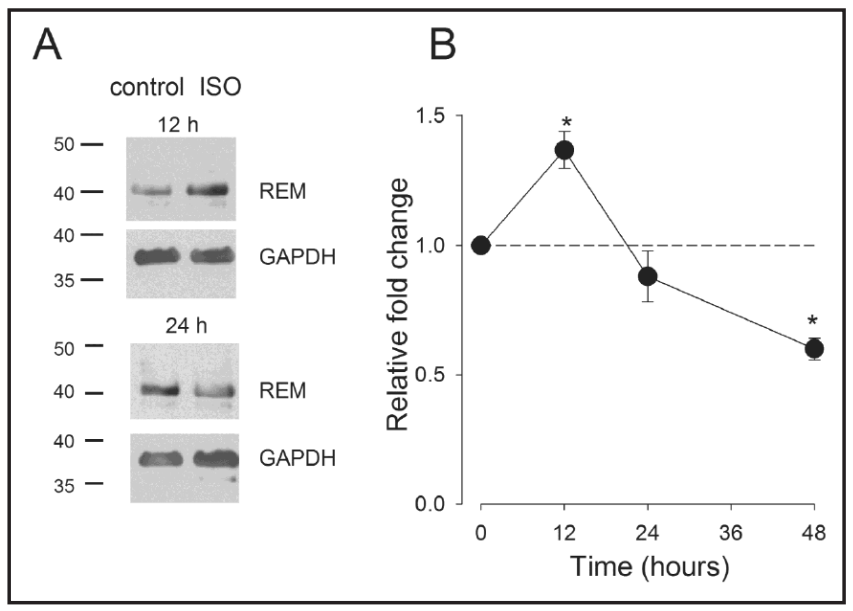

Early regulation of Rem by ISO

A closer examination of the effects of ISO infusion on Rem mRNA expression over time revealed a biphasic time course, peaking at the 12-h time point when an almost 3 -fold increase in Rem mRNA levels; at all other times Rem mRNA expression was actually decreased relative to baseline levels (Fig. 3A). In contrast, miR-132 levels increased monotonically following ISO treatment (no biphasic peaks), with miR-132 levels reaching a plateau that was more than 10-fold baseline levels (Fig. 3B).

Western blot analysis revealed that the time course of Rem protein expression was also biphasic. Ventricle lysates isolated from rats treated with ISO for $12 \mathrm{~h}$ or $24 \mathrm{~h}$ produced Rem bands of increased and decreased density, respectively, relative to controls (Fig. 4A and B). Note that the Rem protein expression increases observed in the 12-h treatment group were quite substantial, reaching up to $40 \%$ of basal levels.

\section{Effects of long-term ISO on Cav1.2 channels}

In patch-clamp experiments, $2 \mathrm{~d}$ ISO treatment did not increase the amplitude of $\mathrm{Ca}^{2+}$ currents as we would have expected given the inhibitory actions of Rem on $\mathrm{Ca}^{2+}$ channel activity (Fig. 5A). L-type $\mathrm{Ca}^{2+}$ currents under control conditions reached a peak of approximately $-5 \mathrm{pA} . \mathrm{pF}^{-1}, 10 \mathrm{~ms}$ after pulse onset. Under control conditions, peak currents were observed at $0 \mathrm{mV}$. The current was not sustained, but rather was inactivated during the pulse via a $\mathrm{Ca}^{2+}$-dependent inactivation process. Currents from ISO-treated rats were smaller and decayed more slowly than those observed in controls. Long-term administration of ISO produced a slight decrease in current density values corresponding to an $8 \%$ decrease in Gmax. A +4 mV shift in the current-voltage relation was also observed. 


\begin{tabular}{|c|c|c|}
\hline Cellular Physiology & Cell Physiol Biochem 2015;36:141-154 & \\
\hline and Biochemistry & $\begin{array}{l}\text { DOI: } 10.1159 / 000374059 \\
\text { Published online: April 30, } 2015\end{array}$ & $\begin{array}{l}\text { Q } 2015 \mathrm{~s} \text {. Karger AG, Basel } \\
\text { www.karger.com/cpb }\end{array}$ \\
\hline
\end{tabular}

Fig. 5. Effects of chronic ISO administration on L-type $\mathrm{Ca}^{2+}$ currents and $\mathrm{Ca}^{2+}$ signals. $A$ : The inset shows representative recordings of L-type $\mathrm{Ca}^{2+}$ currents at $+5 \mathrm{mV}$ steps under control conditions and after 48-h ISO administration. The graph shows mean $( \pm \mathrm{SE}) I-V$ relationship of peak L-type currents. To allow comparisons among experiments, membrane current values were normalized to unit capacitance $\left(\mathrm{C}_{\mathrm{m}}\right) \cdot \mathrm{C}_{\mathrm{m}}=232.9 \pm 7.5(n=44) \mathrm{pF}$ in controls and $\mathrm{C}_{\mathrm{m}}=307.7 \pm 8.0 \mathrm{pF}(n=19)$ in ISO pretreated rats. Peak currents are shown for myocytes isolated from controls $(\bullet ; n=$ 44) and from ISO-pretreated rats $(\boldsymbol{\Lambda} ; n=19)$ at the indicated potentials $\left({ }^{*} p<.05\right.$ between $-20 \mathrm{mV}$ and $0 \mathrm{mV}$ ). The smooth lines are best fit curves for equation (1) with Gmax $=0.12$ $\eta \mathrm{S} . \mu \mathrm{F}^{-1}$ for controls and Gmax $=0.11 \eta \mathrm{S} . \mu \mathrm{F}^{-1}$ for the treatment group. $B$ : The inset shows representative recordings of fluo-3 fluorescent transients. The bar graphs show mean \pm SE $\Delta F / F$ peak values (left) and half-width values (right). Values for myocytes isolated from ISO-pretreated rats $(n=76)$ differed significantly from those obtained from control myocytes $(n=205)$ for half-width only $\left({ }^{*} p<.05\right)$.

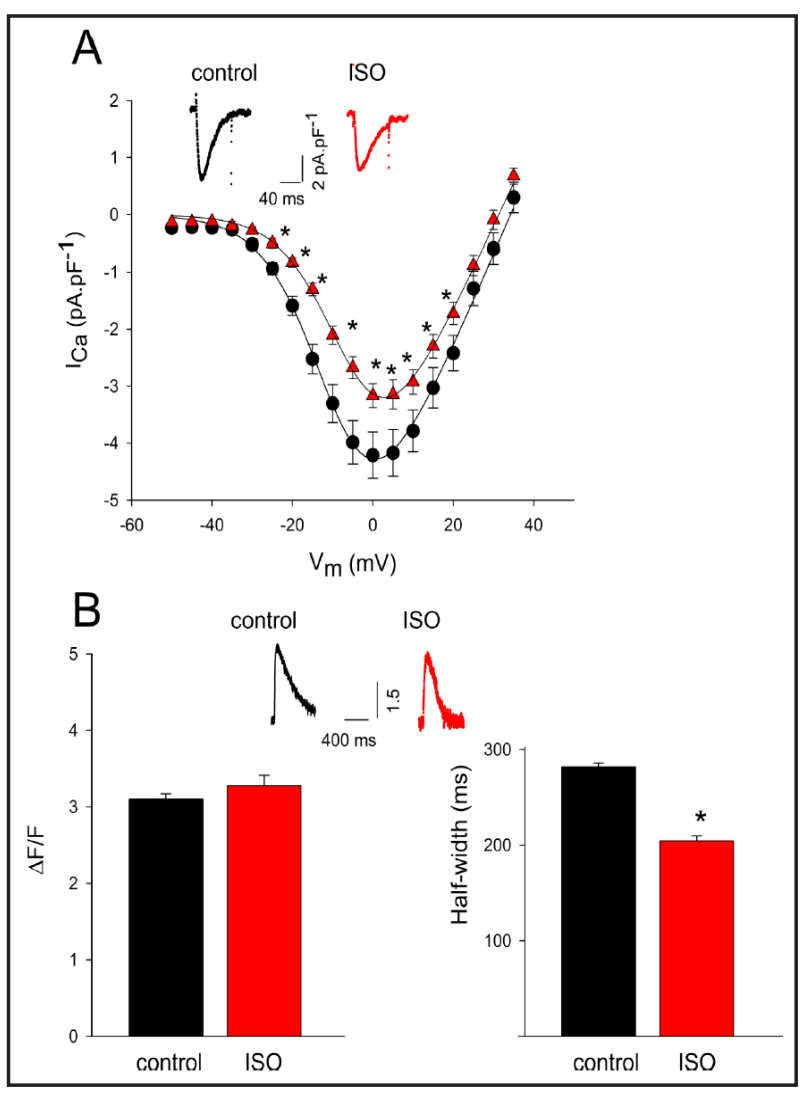

Fig. 6. Changes in $\alpha_{1 c}$ subunit mRNA and protein levels following ISO administration. A: Relationship between ISO administration time and $\alpha_{1 \mathrm{c}}$ subunit mRNA relative expression. Dotted line: level of expression at $\mathrm{t}=0 .(n=3)$. $B$ : Independent immunoblots from control (left) and 48-h ISO-treated (right) ventricle membrane samples representing the $\alpha_{1 c}$ channel subunit (upper panel) and pan-cadherin (lower panel). C: Relationship between ISO administration time and relative protein expression of the $\alpha_{1 c}$ subunit. Values were normalized to pan-cadherin band densities. $(n=3-9)$. Dotted line: level of expression at $\mathrm{t}=0$. All values are group means \pm SEs. $\left.{ }^{*} p<.05\right)$.

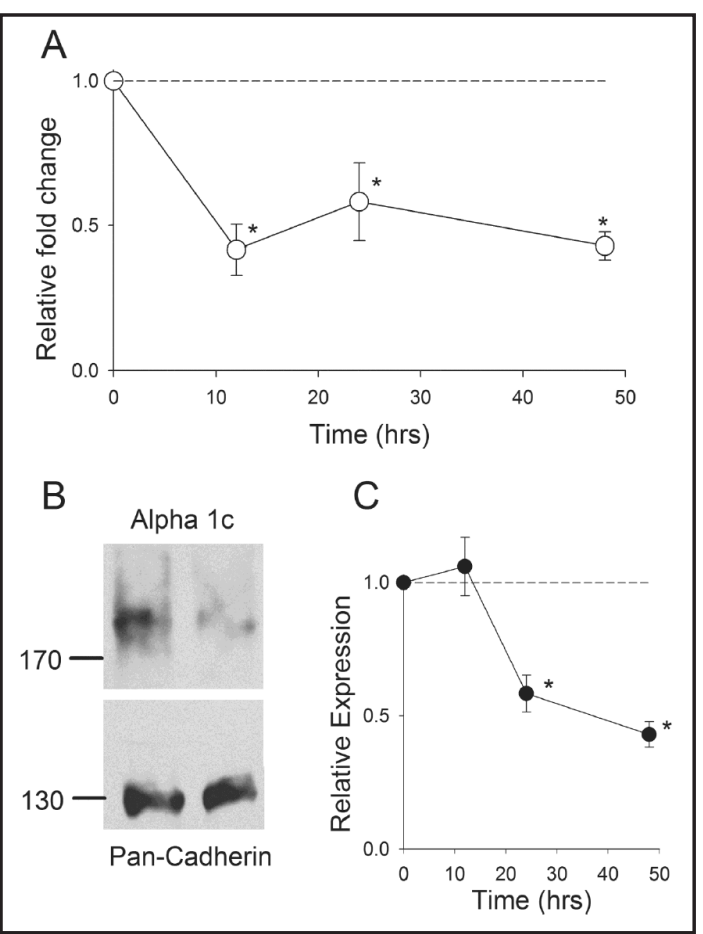

No significant difference was detected in the peak amplitude values of intracellular $\mathrm{Ca}^{2+}$ signals during action potentials, as indexed by fluo-3 fluorescence signals (Fig. 5B), though the signals decayed more rapidly and had smaller half-width values with ISO treatment than without. Hence, the small decreases in current amplitude produced by the ISO treatment had no observable impact on the release of intracellular $\mathrm{Ca}^{2+}$. 


\section{Cellular Physiology Cell Physiol Biochem 2015;36:141-154 \begin{tabular}{ll|l} 
and Biochemistry 10.1159/000374059 & $\begin{array}{l}\text { D 2015 S. Karger AG, Basel } \\
\text { Published online: April 30, 2015 }\end{array}$ & \begin{tabular}{l} 
www.karger.com/cpb \\
\cline { 2 - 3 }
\end{tabular} \\
\cline { 2 - 3 }
\end{tabular} \\ Carrillo et al.: Isoproterenol and Rem Expression}

The unexpected decrease in L-type $\mathrm{Ca}^{2+}$ currents observed after long-term exposure to ISO suggested that chronic $\beta$-agonism may down-regulate Cav1.2 channels. Therefore, we tested the hypothesis that ISO may decrease expression of $\alpha_{1 c}$, the principal subunit of the Cav1.2 channel. We observed significant decreases in both the mRNA and protein levels of the $\alpha_{1 c}$ subunit. The mRNA levels of the $\alpha_{1 c}$ subunit were found to be decreased by $60 \%$ after a 12-h ISO administration period and remained at this low level throughout the remainder of the observation period (Fig. 6A). The decrease in the mRNA transcript levels preceded that of the protein. Thus, western blot experiments showed that the abundance of the $\alpha_{1 \mathrm{c}}$ protein subunit did not change after 12 -h ISO administration, but was decreased significantly at later times. Following ISO treatment for $2 \mathrm{~d}, \alpha_{1 \mathrm{c}}$ subunit abundance fell by $60 \%$ compared to control levels (Fig. 6B,C). The expression of pan-Cadherin (normalization protein) was unaffected by the drug treatment.

\section{Discussion}

In the present study, we demonstrated for the first time that Rem is down-regulated in a posttranscriptional manner by sustained $\beta$-adrenergic receptor activation induced by ISO. qRT-PCR analysis confirmed upregulation of miR-214 and miR-132, miRs that bind the 3'UTR region of Rem, in the hearts of ISO-treated rats. However, only miR-132 exhibited robust regulation in response to ISO, and co-transfection of miR-132, but not of miR-214, repressed expression of a reporter gene regulated by the 3'-UTR of Rem, suggesting that miR-132 may regulate the expression of Rem posttranscriptionally in vivo.

qRT-PCR experiments demonstrated that down-regulation of Rem protein was accompanied by a significant decrease in Rem mRNA levels. This finding is not incompatible with regulation of Rem protein expression at a posttrancriptional level because, although miRs can repress target translation with little change in mRNA levels, mRNA cleavage by miRs has been observed to lead to changes in mRNA abundance $[4,36]$. Rem mRNA showed a distinct peak at $12 \mathrm{~h}$ into a 48-h ISO treatment period, when an almost three-fold increase was observed, followed by a decrease in mRNA abundance compared to control levels. Schroder et al. [24] described a two-fold increase of Rem mRNA $24 \mathrm{~h}$ after ISO infusion in mice, but other ISO periods were not explored. Our data suggest that there is dual regulation of Rem mRNA abundance. Initially, upregulation prevails, but subsequent accumulation of miR-132 appears to lead to down-regulation of Rem at the messenger and protein levels.

Our results are consistent with previous studies relating miR-132 to $\beta$-adrenergic signaling. Vo et al. [37] reported evidence indicating that miR-132 is a target of the transcription factor CREB (cAMP response element) and that the miR-132 response is rapid and long-lasting. Although long-term regulation of Rem via $\beta$-adrenergic stimulation had not been previously explored, regulation of Rem by $\alpha$-adrenergic receptor agonists has been described in neonatal rat cardiomyocytes [25]. In Jhun and colleagues' preparation, sustained stimulation for $2 \mathrm{~h}$ by the $\alpha 1$-adrenergic receptor agonist phenylephrine led to activation of protein kinase D1 and phosphorylation of Rem, resulting in increased L-type current density values and over-expression of Cav1.2 channels in transverse tubular system membranes. The increase in channel expression was attributed to the release of channels from a putative reserve, though possible changes at the mRNA level were not explored [25]. The present results suggest that regulation of Rem by activation of $\beta$-adrenergic receptors involves distinct mechanisms from those associated with $\alpha$-adrenergic stimulation.

Sustained adrenergic activation leads to cardiovascular disorders such as pathological hypertrophy. Hypertrophy develops rapidly in rats. Indeed, Zierhut and Zimmer [15] documented a $40 \%$ increase in the ventricle/body ratio after a 3-day norepinephrine treatment. Carrillo et al. [16] obtained similar results with long-term administration of ISO. Recently, Ucar et al. [9] demonstrated in primary neonatal cardiomyocytes that several hypertrophic stimuli upregulate the expression of miR-132 and that this miR is necessary to drive the hypertrophic growth of cardiomyocytes. The large increase in miR-132 expression 


\section{Cellular Physiology Cell Physiol Biochem 2015;36:141-154 \begin{tabular}{l|l} 
and Biochemistry Published online: April 30, 2015 & $\begin{array}{l}\text { C) 2015 S. Karger AG, Basel } \\
\text { www.karger.com/cpb }\end{array}$ \\
\hline
\end{tabular} \\ Carrillo et al.: Isoproterenol and Rem Expression}

observed in our study with sustained $\beta$-adrenergic activation and cardiac hypertrophy are consistent with this view. Furthermore, miR-132 overexpression developed within hours of ISO administration, reaching a plateau at approximately $12 \mathrm{~h}$. This relatively fast time course is consistent with the development of hypertrophy.

It is likely that other factors beyond miR-132, such as $\mathrm{Ca}^{2+}$-dependent signaling [10], play a role in hypertrophy. Because Cav1.2 channels are regulated by Rem, down-regulation of Rem by miR-132 would be expected to have an impact on $\mathrm{Ca}^{2+}$ homeostasis [19]. Rem is a potent inhibitor of Cav1.2 channel activity and although the inhibitory mechanisms are still being elucidated, the actions of Rem on Cav1.2 currents are thought to be mediated via inhibition of surface expression or inhibition of channel function $[19,38]$. Therefore, downregulation of Rem would be expected to lead to larger Cav1.2 currents. Indeed, Magyar et al. [39] described increased Cav1.2 channel current density values in Rem knock-out mice. In the present study, we evaluated Cav1.2 channel function both indirectly and directly. Our indirect assessment, which entailed the measurement of action potential-associated $\mathrm{Ca}^{2+}$ signals, revealed no changes in the values of peak signals, though we did observe a decrease in half-width values suggestive of a more efficient uptake of $\mathrm{Ca}^{2+}$ by SR. This observation is consistent with the work of Anwar et al. [40], who described an enhancement of SERCA2A expression after chronic ISO stimulation in rat cardiomyocytes in culture. Meanwhile, our direct measurements of Cav1.2 channel currents indicated that although Rem expression was down-regulated by chronic ISO administration, Cav1.2 channel current density values were decreased moderately, rather than increased. Consistent with our results, Zhang et al. [41] found that sustained $\beta$-adrenergic stimulation of cultured adult guinea pig cardiomyocytes for $2 \mathrm{~d}$ led to a reduction in the maximum amplitude of Cav1.2 channel currents. Others have observed minimal changes in Cav1.2 channel current density values following longterm ISO administration. For example, daily injection of ISO for $7 \mathrm{~d}$ led to hypertrophy in rats, but Cav1.2 channel currents were minimally affected [42]. Likewise, in other hypertrophy rat models, Cav1.2 channel current density values remained unchanged [43, 44]. These observations do not rule out a relevant role for Cav1.2 channels in hypertrophy entirely because the small population of these channels housed in caveolae have been shown to contribute very little to whole-cell L-type $\mathrm{Ca}^{2+}$ currents though they play a fundamental role in the nuclear translocation of NFAT (nuclear factor of activated T cells) [45], a well characterized mediator of hypertrophy [46]. Determining whether down-regulation of Rem by chronic ISO leads to an increase in L-type $\mathrm{Ca}^{2+}$ currents in this subpopulation of channels is an important future direction of research.

A reduction in the $\alpha_{1 \mathrm{c}}$ subunit's abundance would be expected to lead to smaller currents because the subunit contains a pore through which $\mathrm{Ca}^{2+}$ ions permeate [47]. Hence, the decreased whole-cell Cav1.2 channel current amplitude observed in this study is likely attributable to the post-ISO decrement in $\alpha_{1 c}$ channel subunit levels. Decreased expression of the $\alpha_{1 \mathrm{c}}$ channel subunit was demonstrated in two sets of experiments. Firstly, reduced $\alpha_{1 \mathrm{c}}$ subunit mRNA levels were observed following ISO administration, particularly at the 12-h post-ISO time point. Secondly, western blot analysis showed reduced $\alpha_{1 \mathrm{c}}$ protein subunit abundance. Given that the half-life of the $\alpha_{1 \mathrm{c}}$ subunit is approximately $25 \mathrm{~h} \mathrm{[48],} \mathrm{a} \mathrm{significant}$ overall reduction at the protein level would be expected following 1-2 $\mathrm{d}$ of $\beta$-adrenergic receptor stimulation, as we did indeed observe. We measured $\alpha_{1 c}$ subunit expression in lysates enriched with the membrane fraction and with cadherin as a normalizer, and observed a significant reduction in levels of the $\alpha_{1 \mathrm{c}}$ subunit of the L-type $\mathrm{Ca}^{2+}$ channel while cadherin levels remained unchanged. Cadherin is a major membrane protein that localizes in specialized cell membrane domains [49], which makes it an ideal plasma membrane marker for cadherin-expressing cells such as cardiac myocytes [50]. While no changes in cadherin were seen by the ISO treatment the levels of the $\alpha_{1 c}$ subunit of the L-type $\mathrm{Ca}^{2+}$ channel were significantly reduced.

Down-regulation of the $\alpha_{1 c}$ subunit could represent a protective mechanism against excessive $\mathrm{Ca}^{2+}$ influx during action potentials. In fact, transgenic overexpression of $\alpha 1 \mathrm{c}$ subunits in mouse hearts led to increased L-type current density values and the mice 


\section{Cellular Physiology Cell Physiol Biochem 2015;36:141-154 \\ \begin{tabular}{l|l|l}
\hline DOI: 10.1159/000374059 & C 2015 S. Karger AG, Basel
\end{tabular} \\ www.karger.com/cpb \\ Carrillo et al.: Isoproterenol and Rem Expression}

developed severe cardiomyopathy indicating that changes in channel density were sufficient to induce disease [26].

In recent years, RGK proteins have emerged as important regulators of Cav1.2 channels and play relevant roles in cells in which $\mathrm{Ca}^{2+}$ acts as a second messenger. The differential expression of the four RGKs is probably related to each RGK's unique role. Rem2, which is most abundantly expressed in brain [22], plays a role in synapse formation and maintenance [51]. Meanwhile, Rem (i.e., Rem1), which is expressed most prominently in heart, modulates the activity of Cav1.2 channels in cardiac myocytes [39], crucial elements in excitation-contraction coupling. Thus, overexpression of Rem dramatically reduces the amplitude of Cav1.2 currents in adult cardiomyocytes [52]. Rad, the other RGK member that is also significantly expressed in heart [20], regulates cardiac Cav1.2 channel activity and its overexpression also leads to smaller Cav1.2 currents [53]. Experiments with knockout mice designed to investigate the role of $\mathrm{Rem}$ on $\mathrm{Ca}^{2+}$ homeostasis have revealed larger cardiac Cav1.2 currents and smaller transient $\mathrm{Ca}^{2+}$ elevations during a twitch. However, Rem deletion results in no obvious cardiac phenotype [39]. Likewise, deletion of Rad leads to larger Cav1.2 currents with no changes in heart weight, body weight or in the heart to body weight ratio, but unlike deletion of Rem, cardiomyocytes from Rad null mice have larger $\mathrm{Ca}^{2+}$ transients $[54,55]$. The susceptibility to cardiac hypertrophy and stress has not been investigated in Rem null mice but ablation of Rad leads to exacerbated cardiac hypertrophy in the thoracic transverse aorta constriction model [56] and to severe cardiac fibrosis [57]. Furthermore, Rad null mice exhibit prolonged QT intervals and diverse arrhythmias [58]. Unlike Rad, Rem expression in cardiomyocytes and other striated muscle cells is maintained throughout myogenic development, suggesting that it may play a role at all stages [30].

Given the diversity of the physiological roles of RGKs, it is not surprising that overall homology among RGKs is relatively low. The homology between Rem and the other RGKs is around $47-58 \%$. Given their heterogeneity, it would be expected that the four RGKs would have different regulatory mechanisms. In this regard, it is interesting to note that the miR132-hybridizing nucleotide sequence of the 3'UTR region of Rem identified in the present work is not present in Rad or in the other RGKs. However, this does not rule out the possibility that the expression of Rad, Rem 2 or Gem/Kir may be also regulated by miRs and given the importance of $\mathrm{Rad}$ on $\mathrm{Ca}^{2+}$ homeostasis in heart, this is an interesting future research topic.

In conclusion, the present work demonstrated that long-term $\beta$-adrenoreceptor agonism results in down-regulation of Rem in rat ventricles at the mRNA and protein levels. Our findings further indicate that this down-regulation does not lead to a whole-cell increase in $\mathrm{Ca}^{2+}$ influx through Cav1.2 channels.

\section{Acknowledgments}

This work was partially supported by CONACYT grant number 167946 to J.A.S. R. Sampieri was supported in part by a fellowship from CONACYT. We thank José M. Galindo for his help in cloning experiments and Eva Sandoval and Oscar Ramírez for technical assistance.

\section{Disclosure Statement}

The authors have no conflict of interest to disclose.

\section{References}

1 Kiriakidou M, Nelson PT, Kouranov A, Fitziev P, Bouyioukos C, Mourelatos Z, Hatzigeorgiou: A combined computational-experimental approach predicts human microRNA targets. Genes Dev 2004;18:1165-1178.

2 Cipolla GA: A non-canonical landscape of the microRNA system. Front Genet 2014; 5:337. 


\section{Cellular Physiology Cell Physiol Biochem 2015;36:141-154 \begin{tabular}{l|l|l} 
DOI: 10.1159/000374059 & (C) 2015 S. Karger AG, Basel
\end{tabular}

3 Valencia-Sanchez MA, Liu J, Hannon GJ, Parker R: Control of translation and mRNA degradation by miRNAs and siRNAs. Genes Dev 2006;20:515-524.

4 He L, Hannon GJ: MicroRNAs: small RNAs with a big role in gene regulation. Nat Rev Genet 2004;5:522-531.

5 Farh KK, Grimson A, Jan C, Lewis BP, Johnston WK, Lim LP, Burge CB, Bartel DP: The widespread impact of mammalian microRNAs. Science 2005;310:1817-1821.

6 Jackson RJ, Standart N: How do microRNAs regulate gene expression? Sci STKE DOI:10.1126/ stke.3672007re1.

$7 \quad$ Sayed D, Abdellatif M: MicroRNAs in development and disease. Physiol Rev 2011;91:827-887.

8 Qi, L, Zhang Y: The microRNA 132 regulates fluid shear stress-induced differentiation in periodontal ligament cells through mTOR signaling pathway. Cell Physiol Biochem 2014;33:433-445.

9 Ucar A., Gupta SK, Fiedler J, Erikci E, Kardasinski M, Batkai S, Dangwal S, Kumarswamy R, Bang C, Holzmann A, Remke J, Caprio M, Jentzsch C, Engelhardt S, Geisendorf S, Glas C, Hofmann TG, Nessling M, Richter K, Schiffer M, Carrier L, Napp LC, Bauersachs J, Chowdhury K, Thum T: The miRNA-212/132 family regulates both cardiac hypertrophy and cardiomyocyte autophagy. Nat Comm 2012;3:1078.

10 Bers DM: Calcium cycling and signaling in cardiac myocytes. Annu Rev Physiol 2008;70:23-49.

11 Shabb JB: Physiological substrates of cAMP-dependent protein kinase. Chem Rev 2001;101:2381-2411.

12 Van der Heyden MA, Wijnhoven TJ, Opthof T: Molecular aspects of adrenergic modulation of cardiac L-type $\mathrm{Ca}^{2+}$ channels. Cardiovasc Res 2005;65:28-39.

13 Nichtova Z, Novotova M, Kralova E, Stankovicova T: Morphological and functional characteristics of models of experimental myocardial injury induced by isoproterenol. Gen Physiol Biophys 2012;31:141-151.

14 Stanton HC, Brenner G, Mayfield ED: Studies on isoproterenol-induced cardiomegaly in rats. Am Heart J 1969;77:72-80.

15 Zierhut W, Zimmer HG: Significance of myocardial alpha- and beta-adrenoceptors in catecholamineinduced cardiac hypertrophy. Circ Res 1989;65:1417-1425.

16 Carrillo ED, Escobar Y, González G, Hernández A, Galindo JM, García MC, Sánchez JA: Posttranscriptional Regulation of the $\beta_{2}$-subunit of cardiac L-type $\mathrm{Ca}^{2+}$ Channels by microRNAs during long-term exposure to isoproterenol in rats. J Cardiovasc Pharmacol 2011;58:470-478.

17 Boluyt MO, Long X, Eschenhagen T, Mende U, Schmitz W, Crow MT, Lakatta EG: Isoproterenol infusion induces alterations in expression of hypertrophy-associated genes in rat heart. Amer J Physiol Heart Circ Physiol 1995;269:H638-H647.

18 Greenwood JP, Scott EM, Stoker JB, Mary DA: Hypertensive left ventricular hypertrophy: relation to peripheral sympathetic drive. J Am Coll Cardiol 2001;38:1711-1717.

19 Flynn R, Zamponi GW: Regulation of calcium channels by RGK proteins. Channels 2010;4:434-439.

20 Reynet C, Kahn CR: Rad: A member of the Ras family overexpressed in muscle of type 11 diabetic humans. Science 1993;262:1441-1444.

21 Maguire J, Santoro T, Jensen P, Siebenlist U, Yewdell J, Kellyt K: Gem: An induced, immediate early protein belonging to the Ras family. Science 1994;265:241-243.

22 Finlin BS, Shao H, Kadono-Okuda K, Guo N, Andres DA: Rem2, a new member of the Rem/Rad/Gem/Kir family of Ras-related GTPases. Biochem J 2000;347:223-231.

23 Finlin BS, Andres DA: Rem is a new member of the Rad and Gem/Kir Ras-related GTP-binding protein family repressed by lipopolysaccharide. J Biol Chem 1997;272:21982-21988.

24 Schroder E, Magyar J, Burgess D, Andres D, Satin J: Chronic verapamil treatment remodels ICa,L in mouse ventricle. Am J Physiol Heart Circ Physiol 2007;292:1906-1916.

25 Jhun BS, O-Uchi J, Wang W, Ha CH, Zhao J, Kim JY, Wong C, Dirksen RT, Lopes CMB, Jin ZG: Adrenergic signaling controls RGK-dependent trafficking of cardiac voltage-gated L-type $\mathrm{Ca}^{2+}$ channels through PKD1. Cir Res 2012;110:59-70.

26 Muth JN, Bodi I, Lewis W, Varadi G, Schwartz A: A Ca ${ }^{2+}$-dependent transgenic model of cardiac hypertrophy: A role for protein kinase C $\alpha$. Circulation 2001;103:140-147.

27 Kruger J, Rehmsmeier M: RNAhybrid: microRNA target prediction easy, fast and flexible. Nucleic Acids Res 2006;34:W451-W454.

28 González G, Zaldívar D, Carrillo ED, Hernández A, García MC, Sánchez JA: Pharmacological preconditioning by diazoxide downregulates cardiac L-type $\mathrm{Ca}^{2+}$ channels. Brit J Pharmacol 2010;161:1172-1185.

29 Saada NI, Carrillo ED, Daia B, Wanga W, Dettbarna C, Sanchez JA, Palade P: Expression of multiple CaV1.2 transcripts in rat tissues mediated by different promoters. Cell Calcium 2005;37:301-309. 


\section{Cellular Physiology Cell Physiol Biochem 2015;36:141-154 \begin{tabular}{l|l|l} 
DOI: 10.1159/000374059 & (C) 2015 S. Karger AG, Basel
\end{tabular} www.karger.com/cpb

30 Finlin BS, Crump SM, Satin J, Andres DA: Regulation of voltage-gated calcium channel activity by the Rem and Rad GTPases. Proc Natl Acad Sci USA 2003;100:14469-14474.

31 Bradford MM: A rapid and sensitive method for the quantitation of microgram quantities of protein utilizing the principle of protein-dye binding. Anal Biochem 1976;72:248-254.

32 Romero-Calvo I, Ocón B, Martínez-Moya P, Suárez MD, Zarzuelo A, Martínez-Augustin O, Sánchez de Medina F: Reversible Ponceau staining as a loading control alternative to actin in Western blots. Anal Biochem 2010;401:318-320.

33 Schmittgen TD: Quantitative gene expression by real-time PCR: A complete protocol; in: Dorak T (ed): Realtime PCR. New York, Taylor \& Francis, 2006, pp127-137.

34 Livak KJ, Schmittgen TD: Analysis of relative gene expression data using real-time quantitative PCR and the $2^{-\Delta \Delta C T}$ method. Methods 2001;25:402-408.

35 Clancy JL, Nousch M, Humphreys DT, Westman BJ, Beilharz TH, Preiss T: Methods to Analyze MicroRNAMediated Control of mRNA Translation. Method Enzymol 2007;431:83-111.

36 Chekanova JA, Belostotsky DA: MicroRNAs and Messenger RNA Turnover. Methods Mol Biol 2006;342:7385.

37 Vo N, Klein ME, Varlamova O, Keller DM, Yamamoto T, Goodman RH, Impey S: A cAMP-response element binding protein-induced microRNA regulates neuronal morphogenesis. PNAS 2005;102:16426-16431.

38 Yang T, Colecraft HM: Regulation of voltage-dependent calcium channels by RGK proteins. BBA Biomembranes 2013;1828:1644-1654.

39 Magyar J, Kiper CE, Sievert G, Cai W, Shi GX, Crump SM, Li L, Niederer S, Smith N, Andres DA, Satin J: REM GTPase regulates cardiac myocyte L-type calcium current. Channels 2012;6:166-173.

40 Anwar A, Schlüter KD, Heger J, Piper HM, Euler G: Enhanced SERCA2A expression improves contractile performance of ventricular cardiomyocytes of rat under adrenergic stimulation. Pflugers Arch Eur J Physiol 2008;457:485-491.

41 Zhang LM, Wang Z, Nattel S: Effects of sustained $\beta$-adrenergic stimulation on ionic currents of cultured adult guinea pig cardiomyocytes. Am J Physiol Heart Circ Physiol 2002;282:H880-H889.

42 Meszaros J, Coutinho JJ, Bryant SM, Ryder KO, Hart G: L-type calcium current in catecholamine-induced cardiac hypertrophy in the rat. Exp Physiol 1997;82:71-83.

43 Scamps F, Mayoux E, Charlemagne D, Vassort G: Calcium current in single cells isolated from normal and hypertrophied rat heart. Effects of beta-adrenergic stimulation. Circ Res 1990;67:199-208.

44 Delbridge LM, Satoh H, Yuan W, Bassani JW, Qi M, Ginsburg KS, Samarel AM, Bers DM: Cardiac myocyte volume, $\mathrm{Ca}^{2+}$ fluxes, and sarcoplasmic reticulum loading in pressure-overload hypertrophy. Am J Physiol Heart Circ Physiol 1997;272:H2425-H2435.

45 Makarewich CA, Correll RN, Gao H, Zhang H, Yang B, Berretta RM, Rizzo V, Molkentin JD, Houser SR: A caveolae-targeted L-type $\mathrm{Ca}^{2+}$ channel antagonist inhibits hypertrophic signaling without reducing cardiac contractility. Novelty and significance. Circ Res 2012;110:669-674.

46 Wilkins BJ, Molkentin JD: Calcium-calcineurin signaling in the regulation of cardiac hypertrophy. Biochem Biophys Res Commun 2004;322:1178-1191.

47 Catterall WA: Voltage-gated calcium channels. Cold Spring Harb Perspect Biol DOI: 10.1101/cshperspect. a003947.

48 Catalucci D, Zhang DH, DeSantiago J, Aimond F, Barbara G, Chemin J, Bonci D, Picht E, Rusconi F, Dalton ND, Peterson KL, Richard S, Bers DM, Brown JH, Cordorelli G: Akt regulates L-type $\mathrm{Ca}^{2+}$ activity by modulating CaV $\alpha 1$ protein stability. J Cell Biol 2009;184:923-933.

49 Angst BD, Marcozzi C, Magee AI: The cadherin superfamily: diversity in form and function. J Cell Sci 2001;114:629-641.

50 Doyle DD, Goings GE, Upshaw-Earley J, Page E, Ranscht B, Palfrey HC: T-cadherin is a major glycophosphoinositol-anchored protein associated with noncaveolar detergent-insoluble domains of the cardiac sarcolemma. J Biol Chem 1998;273:6937-6943.

51 Paradis S, Harrar DB, Lin Y, Koon AC, Hauser JL, Griffith EC, Zhu L, Brass LF, Chen C, Greenberg ME: An RNAi-based approach identifies molecules required for glutamatergic and GABAergic synapse development. Neuron 2007;53:217-232.

52 Xu X, Marx SO, Colecraft HM: Molecular mechanisms, and selective pharmacological rescue, of Reminhibited CaV1.2 channels in heart. Circ Res 2010;107:620-630. 
53 Wang G, Zhu X, Xie W, Han P, Li K, Sun Z, Wang Y, Chen C, Song R, Cao C, Zhang J, Wu C, Liu J, Cheng H: Rad as a novel regulator of excitation-contraction coupling and beta-adrenergic signaling in heart. Circ Res 2010;106:317-327.

54 Manning JR, Yin G, Kaminski CN, Magyar J, Feng HZ, Penn J, Sievert G, Thompson K, Jin JP, Andres DA, Satin J: Rad GTPase deletion increases L-type calcium channel current leading to increased cardiac contraction. J Am Heart Assoc DOI: 10.1161/JAHA.113.000459.

55 Yamakawa H, Murata M, Suzuki T, Yada H, Ishida H, Aizawa Y, Adachi T, Kamiya K, Fukuda K: Suppression of Rad leads to arrhythmogenesis via PKA-mediated phosphorylation of ryanodine receptor activity in the heart. Biochem Biophys Res Commun 2014;452:701-707.

56 Chang L, Zhang J, Tseng YH, Xie CO, Ilany J, Brünning JC, Sun Z, Zhu X, Cui T, Youker KA, Yang Q, Day SM, Kahn CR, Chen YE: Rad GTPase deficiency leads to cardiac hypertrophy. Circulation 2007;116:2976-2983.

57 Zhang J, Chang L, Chen C, Zhang M, Luo Y, Hamblin M, Villacorta L, Xiong JW, Chen YE, Zhang J, Zhu X: Rad GTPase inhibits cardiac fibrosis through connective tissue growth factor. Cardiovasc Res 2011;91:90-98.

58 Yada H, Murata M, Shimoda K, Yuasa S, Kawaguchi H, Ieda M, Adachi T, Murata M, Ogawa S, Fukuda K: Dominant negative suppression of Rad leads to QT prolongation and causes ventricular arrhythmias via modulation of L-type $\mathrm{Ca}^{2+}$ channels in the heart. Circ Res 2007;101:69-77. 